\title{
Viewpoint: Soda taxes - four questions economists need to address
}

\section{Laura Cornelsen 1, Richard D Smith 1}

1 Faculty of Public Health and Policy, London School of Hygiene and Tropical Medicine, 15-17 Tavistock Place, WC1H 9SH London, UK

Corresponding author: Laura Cornelsen; laura.cornelsen@Ishtm.ac.uk

\begin{abstract}
The popularity of soda taxes as a public health policy has grown rapidly in the last few years. While the evidence that the tax works in reducing the purchases of soda is emerging, there are a number of questions that are yet to be answered before the broader effectiveness of this measure can be determined. Beyond health effects, there is more specifically a need to better understand the economic mechanisms of change, redistributive effects, as well as causal and spillover effects in food systems and economy more broadly.
\end{abstract}

Keywords: tax; soda; sugary drink; SSB; effect; economic impact

\section{Highlights}

- Increasing number of countries are considering or implementing soda taxes

- Taxes are shown to have reduced purchases of taxed sodas

- Better understanding is needed on mechanisms driving change, including media framing

- Taxes incentivising reformulation likely to have different consequences on consumption and revenues

- Health, redistributive and wider economic impacts are yet to be determined

\section{Acknowledgments}

LC is funded via UK MRC Career Development fellowship (MR/P021999/1)

Viewpoint: Soda taxes - four questions economists need to address 


\section{Introduction}

In the last few years the list of countries that have implemented a soda tax, or plan to, has grown rapidly (see table 1). The popularity of this upstream public health policy, designed to reduce consumption of sugar, is exceptional. The first ex-post evaluations suggest soda taxes work in reducing purchases of taxed products (see table 2). In Mexico, the demand for sugary drinks fell by 6-9\% in the first two years after implementation of a tax that increased price on average by $10 \%$ (Colchero et al., 2017b, Colchero et al., 2015). In Berkley, California, sales data indicated a 9\% decline in purchases, while self-reported changes in consumption amounted to a $21 \%$ reduction of taxed sodas (Falbe et al., 2016, Silver et al., 2017). In Finland, Hungary and France, although rigorous evaluations have not yet been undertaken, reports also indicate reductions in demand (Cornelsen and Carreido, 2015). Yet, while seemingly straightforward, the effects become complex once we look deeper and wider (Penney et al., 2017). How thoroughly do we understand the direct and indirect mechanisms and effects of these taxes; not only on health outcomes but also on the wider economy? In this viewpoint, we outline four core questions that require greater engagement from economists in the design and evaluation of this health policy intervention to ensure it meets its potential.

\section{Mechanism for behaviour change: price or signalling effect?}

Implementation of soda tax is generally preceded and accompanied with significant debates in the media between specialists and advocates from both (public) health and the food industry. The former generally focus on the negative health effects of (over) consuming sugar or sodas and its associations with obesity and disease; calling for measures such as the tax and suggesting that revenues, if earmarked for health, nutrition or education, can yield even greater benefits (Niederdeppe et al., 2013, Nixon et al., 2015, Elliott-Green et al., 2016, Jeong et al., 2014). The pro-industry coverage emphasises the importance of consumer choice, individual responsibility and exercise, disassociates the products from negative health outcomes and generally refers to the tax as a regressive measure with negative consequences on the poor, jobs and the economy (Niederdeppe et al., 2013, Nixon et al., 2015, Elliott-Green et al., 2016).

The question therefore arises of whether the price increase that the tax eventually causes (which could both fall short or exceed the expected value of the tax (Berardi et al., 2016, Falbe et al., 2015, Cawley and Frisvold, 2017, Silver et al., 2017, Colchero et al., 2015)), is the main driver for behaviour change, such as observed in Berkeley and Mexico, or the framing of the tax as a health (or economy) related measure, including in the media, has a significant role?

For example, a recent study analysing changes in the sales from a voluntary levy on sugary drinks, implemented in a chain of 37 restaurants in the UK, found a large reduction in the sales (9.3\%) relative to a modest increase in price (about 3.5\%). However, the levy was supported with different activities, including redesigned beverage menu with text explaining why the levy was introduced, new products on the drinks menu as well as numerous articles in press and a documentary screened in a national TV channel, so it is likely that these other activities also influenced consumer behaviour (Cornelsen et al., 2017).

A study reviewing British mainstream media in 2014 found 374 articles published on sugar-sweetened beverages (more than one article per day). Of these, $81 \%$ suggested that these drinks are unhealthy, although only $24 \%$ suggested any policy change (Elliott-Green et al., 2016). In the USA, local taxes are being voted for in a ballot which is preceded with explicit campaigns on both sides (Paarlberg et al., 2017) and is likely to raise awareness. Such framing effects are very difficult to measure as the information in media appears over time and starts well before a tax is implemented. However, for 
example, a study of a relatively small, $5 \%$ sales tax on soft drinks, unrelated to health (Maine (1991) and Ohio (2003)), found no changes in sales arising from this measure (Calantuoni and Rojas, 2015) suggesting also that price may not be the only driver.

A further, related, issue that may determine the effectiveness of the tax is whether, once introduced, the tax is signalled to the consumer on the price tag, shelf price or receipt serving as a reminder of the tax. There is emerging literature (particularly from the USA) on tax salience suggesting that taxes which are posted (signalled) in prices reduce consumption more than increases in sales taxes which are added at the register (Chetty et al., 2009, Chen et al., 2015, Zheng et al., 2013). This issue has not been extensively studied in the context of soda taxes but it relates back to the design of the taxes and at which stage of the supply chain the tax is applied (e.g. if levied on the producer, it is difficult for the retailer to know the exact amount to post on the price).

If taxes indeed are more salient and consumer response stronger when tax is signalled in the posted price, there are important implications to revenue collection from the tax. Simply put, if the aim is to raise revenue, the tax should not be posted and if the aim is to reduce consumption, the tax should be posted and well signalled to the consumer. Contrary to cigarette taxes, the ability of a soda tax to raise revenue is already more limited because the own-price elasticity is greater (in absolute terms) for sodas (estimated at -0.8 to -1.2 by meta-analyses vs -0.4 to -0.7 for cigarettes (Andreyeva et al., 2010, Cabrera Escobar et al., 2013, Green et al., 2013, Jha, 2009, Gallet and List, 2003, IARC, 2011)).

\section{Comprehensiveness of the purchasing behaviours: are we getting the full picture?}

When it comes to the effectiveness of soda taxes, evidence stems largely from data collected on purchases for at-home consumption (i.e. based on home-scan data). Beyond experimental studies, there is little evidence on how a soda tax influences consumer purchases out-of-home; for example in work places, cafeterias and (fast-food) restaurants. Consumption in these places can be significant. For example, in the USA, consumers' daily average intake from sodas is $213 \mathrm{kcal}$, of which $135 \mathrm{kcal}$ (74\%) is purchased from supermarkets or convenience stores (An and Maurer, 2016) and, likely to be consumed at home. A significant minority is consumed at fast-food restaurants, full-service restaurants, vending machines and other sources. In the UK, a recent study compared beverage consumption by location using the National Diet and Nutrition Survey data from 845 children aged 413. All the children reported beverage consumption at home with average soda intake $<25 \mathrm{~g} /$ day. While less than quarter of these children reported consuming any beverages in fast-food or full-service restaurants and cafes, the consumption of sodas was highest in these locations (106g/day and $110 \mathrm{~g} /$ day, respectively) (Vieux et al., 2017). Going forward it is important to see how soda taxes are passed on to consumers in these other purchase locations and how this may affect purchase and consumption. Understanding these effects would also help understand how complementary policies, such as the ban on vending machines in schools or sales of supersized or fixed-price drinks (e.g. as in France) could affect consumption and diets.

One of the main counterarguments to implementing soda taxes is its regressive nature as low-income households tend to consume more of these beverages (Cornelsen and Carreido, 2015). Because of lower incomes it is likely, however, that low-income consumers are also more responsive to changes in prices so presumably they would also reduce consumption relatively more (Wada et al., 2015), but whether that carries through to proportionally higher health benefits is yet to be demonstrated.

To understand the health effects it is crucial to understand if soda taxes have a broader effect on purchase decisions beyond the taxed products (Cornelsen et al., 2014). Are there substitution, complementarity or budget effects towards untaxed beverages, other sugary products (e.g. 
confectionary, biscuits, chocolates, desserts) and healthier foods, such as fruits or vegetables? The existing evaluations from Mexico and Berkley that looked at untaxed beverage alternatives suggest some substitution towards water (see table 2), but broader evaluations of the effects of implemented taxes, exploring substitution within the full food basket (including in longer run) remain to be done.

\section{What is the impact of incentivising reformulation versus reduced consumption?}

In comparison to taxes implemented thus far in Mexico, France, and in parts of the USA, some recent proposed taxes fundamentally differ, and are more complex. For example, the sugary drinks levy proposed in the UK, has tax rates set at different levels depending on the sugar content in the beverages, and the objective is not to reduce soda purchases per se but to reduce the consumption of sugar through giving companies incentives to "remove added sugar, promote diet drinks, and reduce portion sizes for high sugar drinks" as drinks containing less sugar will be taxed at a lower rate or not at all (HM Treasury, 2016a).

And while sodas with high sugar content, in the UK for example, comprise about half of the soft-drinks market, the mid-range category (subject to a smaller levy), is growing and the industry is keen to show its efforts at reformulating (BSDA, 2017). In the anticipation of a number of these efforts, UK government has already had to reduce expectations of revenues raised (Daneshku, 2017). Another uncertainty is whether or not the tax is passed through to the price of sodas, as it is levied upon the producer, not the retailer, who can apply different pricing strategies to its entire product portfolio. This includes changing the prices of non-taxed products also, depending on their projections of consumer demand and price responsiveness.

In evaluating the possible economic impact of such multi-tiered taxes, and/or those targeted at producers not consumers, we need to consider several scenarios that account for product reformulation and replacement, price increases of taxed products and untaxed alternatives, as well as the wider redistributive effects in the economy. In this respect, a useful comparison could be made between the effects observed in Catalonia where taxes are two-tiered but mandatory for retailers to pass it on to consumers (Generalitat de Catalunya, 2017), versus the UK or Ireland where the planned taxes will be levied on producers and pass-through to prices left to the discretion of the manufacturers.

\section{What is the impact on the economy more widely?}

Even if prices do increase for certain drinks, and their consumption falls as a consequence, the economic impact is ambiguous at best, given substitution patterns across drink and food. Media coverage of soda taxes include threats by the industry of the negative consequences on jobs and company tax revenues from reduced demand (Oxford Economics, 2016). However, much of this debate - on both sides - misses the critical point that even if we do not know on what exactly, it is likely that the money not spent on soft drinks will be spent on other products (be it beverages or food). If the price of soda increases following a tax and consumers substitute to, say, water that is produced by same producer, revenues simply shift rather than fall away (Richardson, 2016). Similarly, if consumers now have three beers rather than two beers and one cola, bar and restaurant revenues might actually increase (and of course health may not).Therefore, redistributive effects, both within the drinks industry and related businesses and across the food and drinks industry at large are likely to occur, albeit possibly only over time.

We also need to look beyond the food and drink industry and consider the wider economy. In the case of the UK levy, the policy also refers to increasing investment in physical activity interventions and healthy school-meals for children. In this case, there may be increased employment in the physical 
activity sector, and the associated publicity may further increase demand for health-club membership, trainers or sports equipment (Penney et al., 2017).

Finally, a dimension to consider is geographical effects. For example, the localised taxes in the USA, in relatively small jurisdictions, are likely to see at least some level of increased "cross-border" shopping which in turn will affect tax pass through rates and revenues collected (Cawley and Frisvold, 2017). Is there an optimal geographical spread and magnitude of the tax that would avoid this? More globally, if taxes do work and consumption falls in countries where this measure has been adopted, are we pushing the problem to other markets, particularly those in lower-middle income countries with large growth potential for these types of beverages (Euromonitor Passport, 2015, Goryakin et al., 2017, Roache and Gostin, 2017)? There are lessons to learn here perhaps from the stricter tobacco control policies in high-income countries being associated with increased marketing and consumption in lowand middle-income countries (Savell et al., 2015).

\section{Conclusion: what economists need to analyse}

To address the issues above, there are numerous aspects surrounding soda taxes that have or are about to be implemented that urgently need input from the economics discipline to:

- Continue to thoroughly assess the impact of soda taxes, on purchases of both taxed and non-taxed products, including by income gradient and beyond the immediate geographical boundaries of the tax;

- Study the substitution effects in greater detail, using alternative approaches to demand analysis where aggregation of products may mask important patterns;

- Understand the mechanisms of change in current, implemented, taxes and the role of framing the taxes through media debates (or ballots as in the US) and its (synergistic) effects in combination with price changes;

- Conduct a wider analysis of both direct and indirect costs and benefits on the economy arising from the taxes, including arising from reformulation efforts.

In sum, soda taxes are becoming a defining economic intervention within public health, targeting large populations and perhaps second only to measures implemented in limiting consumption of tobacco in the past decades. However, understanding the economic mechanisms and impacts has been scarce while the taxes are now being rapidly implemented without a real consideration of the likely causal and spillover effects in food systems and economy. If this major economic intervention is to achieve its potential, then it urgently requires economists to be involved in grappling with these critical questions. 


\section{Table 1. Planned and recently implemented soda taxes}

\begin{tabular}{|c|c|c|}
\hline Country & Date & Details \\
\hline \multicolumn{3}{|l|}{ Planned } \\
\hline $\begin{array}{l}\text { United } \\
\text { Kingdom }\end{array}$ & April 2018 & $\begin{array}{l}\text { Two-tiered levy on producers of sugary beverages. Tax rates are } f 0.18 / \mathrm{L} \text { for drinks } \\
\text { containing 5-8g of sugar } / 100 \mathrm{ml} \text { and } £ 0.24 \text { for drinks containing }>8 \mathrm{~g} \text { of sugar } / 100 \mathrm{ml} \text {; } \\
\text { revenues earmarked for school sports and educational programs (HM Treasury, 2016b) }\end{array}$ \\
\hline Ireland & April 2018 & $\begin{array}{l}\text { Follows proposals of the UK levy (above). Tax rates will are } € 0.2 / L \text { for drinks containing } \\
5-8 \mathrm{~g} \text { of sugar } / 100 \mathrm{ml} \text { and } € 0.3 \text { for drinks containing }>8 \mathrm{~g} \text { of sugar } / 100 \mathrm{ml} \text { (Department of } \\
\text { Finance, 2016) }\end{array}$ \\
\hline $\begin{array}{l}\text { Seattle } \\
\text { (US) }\end{array}$ & Jan 2018 & $\begin{array}{l}\text { 1.75-cent tax on sodas, sports drinks, energy drinks and other sweet drinks (distributors } \\
\text { pay tax) }(2017 \text {, Norimine, 2017). }\end{array}$ \\
\hline $\begin{array}{l}\text { San Francisco } \\
\text { (US) }\end{array}$ & Jan 2018 & $\begin{array}{l}\text { 1-cent per fluid ounce excise tax on the distribution of sugar-sweetened beverages } \\
\text { Excludes milk products, } 100 \% \text { juice, diet drinks (Treasurer\&Tax Collector, 2017). }\end{array}$ \\
\hline \multicolumn{3}{|r|}{ ( } \\
\hline Estonia & $\begin{array}{l}\text { Intended } \\
\text { Jan 2018; } \\
\text { delayed }\end{array}$ & $\begin{array}{l}\text { Two-tiered levy on producers of sugary beverages. Tax rates are } € 0.1 / \mathrm{L} \text { for drinks } \\
\text { containing artificial sweeteners, juices with no added sugar or added sugar up to } \\
8 \mathrm{~g} / 100 \mathrm{ml} \text {; } € 0.3 / \mathrm{L} \text { for drinks with }>8 \mathrm{~g} \text { of sugar } / 100 \mathrm{ml} \text {. To allow for reformulation the } \\
€ 0.3 \text { rate was initially set with a threshold of } 10 \mathrm{~g} \text { of sugar/100ml (2018), then } 9 \mathrm{~g}(2019) \\
\text { and } 8 \mathrm{~g} \text { by } 2020 \text { (Veerman and Thai, } 2017, \mathrm{WHO}, 2017, \mathrm{ERR}, 2017) \text {. }\end{array}$ \\
\hline South Africa & $\begin{array}{l}\text { Intended } \\
\text { April 2017; } \\
\text { delayed }\end{array}$ & $\begin{array}{l}\text { Implementation of the tax has been delayed and lower, revised tax rates introduced. } \\
\text { Tax applies to sweetened beverages with }>4 \mathrm{~g} \text { of sugar } / 100 \mathrm{ml} \text { (including pure fruit } \\
\text { juices); tax rate is } 2.1 \mathrm{c} \text { per } \mathrm{g} \text { of sugar in each } 100 \mathrm{ml} \text { beyond } 4 \mathrm{~g} / 100 \mathrm{ml} \text { (National } \\
\text { Treasury Republic of South Africa, 2016, National Treasury Republic of South Africa, } \\
\text { 2017). }\end{array}$ \\
\hline \multicolumn{3}{|c|}{ Implemented since 2015} \\
\hline $\begin{array}{l}\text { United Arab } \\
\text { Emirates }\end{array}$ & Oct 2017 & $50 \%$ tax on carbonated drinks, 100\% tax on energy drinks (Burki, 2017, WCRF, 2017). \\
\hline Thailand & Sept 2017 & $\begin{array}{l}\text { Excise tax levied on sugar-sweetened beverages over } 6 \text {-year phased period to } \\
\text { encourage reformulation. Tax rates to be announced; drinks divided into five categories } \\
\text { based on sugar content per } 100 \mathrm{~g} \text { : below } 6 \mathrm{~g}, 6-10 \mathrm{~g} \text {, more than 10-14g, more than 14- } \\
18 \mathrm{~g} \text { and more than } 18 \mathrm{~g} \text { (Chantanusornsiri, 2017, Jitpleecheep, 2017). }\end{array}$ \\
\hline $\begin{array}{l}\text { Cook County, } \\
\text { IL (US) }\end{array}$ & $\begin{array}{l}\text { August } \\
2017 ; \\
\text { Repealed } \\
\text { Oct } 2017\end{array}$ & $\begin{array}{l}\text { 1-cent per ounce tax on sugar-sweetened beverages sold at retail in the County. } \\
\text { Exclusions include milk products, } 100 \% \text { juice, diet drinks. The distributor or retailer } \\
\text { must include the tax in the sale price of the sweetened beverages (Cook County } \\
\text { Government, 2017). }\end{array}$ \\
\hline $\begin{array}{l}\text { Boulder, CO } \\
\text { (US) }\end{array}$ & July 2017 & $\begin{array}{l}\text { 2-cent per fluid ounce of sugar-sweetened beverage product excise tax on the } \\
\text { distributors of the beverages (containing at least } 5 \mathrm{~g} \text { of added caloric sweetener per } 12 \\
\text { ounce) (City of Boulder, 2017). }\end{array}$ \\
\hline $\begin{array}{l}\text { Oakland, CA } \\
\text { (US) }\end{array}$ & July 2017 & $\begin{array}{l}\text { 1-cent per fluid ounce excise tax on the distribution of sugar-sweetened beverages } \\
\text { containing at least } 2 \mathrm{kcal} / \text { ounce. Milk based beverages and beverages with non-caloric } \\
\text { sweeteners are exempt (City of Oakland, 2016). }\end{array}$ \\
\hline Saudi Arabia & June 2017 & $50 \%$ tax on carbonated drinks, $100 \%$ tax on energy drinks (WCRF, 2017) \\
\hline $\begin{array}{l}\text { Albany, CA } \\
\text { (US) }\end{array}$ & April 2017 & $\begin{array}{l}\text { 1-cent per fluid ounce excise tax on the distribution of sugar-sweetened beverages } \\
\text { (defined as containing at least } 2 \mathrm{kcal} \text { per ounce and added sweetener). Exclusions } \\
\text { include milk products, } 100 \% \text { juice, diet drinks (City of Albany, 2017). }\end{array}$ \\
\hline $\begin{array}{l}\text { Catalonia } \\
\text { (Spain) }\end{array}$ & April 2017 & $\begin{array}{l}\text { Two-tiered tax on drinks that contain added caloric sweeteners. Tax rates are } € 0.08 / \mathrm{L} \\
\text { for drinks with } 5-8 \mathrm{~g} \text { of sugar per } 100 \mathrm{ml}, € 0.12 \text { for drinks with }>8 \mathrm{~g} \text { of sugar per } 100 \mathrm{ml} \text {. } \\
\text { Tax is mandatory to pass through to sales prices (Baquero, 2017, Agencia Tributaria de } \\
\text { Catalunya, 2017, Generalitat de Catalunya, 2017) }\end{array}$ \\
\hline Brunei & April 2017 & Excise duty of $(\sim \$ 0.28 / L)$ of SSBs with $>6 \mathrm{~g}$ of total sugar per $100 \mathrm{ml}(\mathrm{WCRF}, 2017)$ \\
\hline Portugal & Feb 2017 & $\begin{array}{l}\text { Special Consumption Tax (VAT). Drinks with }<8 \mathrm{~g} \text { of sugar } / 100 \mathrm{ml} \text { are taxed at } € 8.2 \text { per } \\
100 \mathrm{~L} \text {, and drinks with }>8 \mathrm{~g} \text { of sugar } / 100 \mathrm{ml} \text { are taxed at } € 16.46 \text { per } 100 \mathrm{~L} \text {. Milk based } \\
\text { beverages and natural juices are excluded from the tax. Revenues are earmarked for } \\
\text { National Health Service (Agence France-Presse, 2016, The Portugal News Online, 2017, } \\
\text { Autoridade Tributaria e Aduaneira, 2017). }\end{array}$ \\
\hline $\begin{array}{l}\text { Philadelphia } \\
\text { (US) }\end{array}$ & Jan 2017 & $\begin{array}{l}\text { 1.5-cents per ounce excise tax on distributors of sugar-sweetened beverages. Tax } \\
\text { excludes milk products, } 100 \% \text { juice, diet drinks (City of Philadelphia, 2017). }\end{array}$ \\
\hline Dominica & Sep 2015 & $10 \%$ excise tax to drinks with high sugar content \\
\hline Barbados & Sep 2015 & $10 \%$ excise tax on sugar sweetened beverages (Alvarado et al., 2017). \\
\hline Mauritius & Oct 2016 & $\begin{array}{l}\text { Excise tax of } \sim \$ 0.08 \text { per } 100 \mathrm{~g} \text { of sugar content in beverages containing sugar, including } \\
\text { juices, milk based beverages and soft drinks (WCRF, 2017). }\end{array}$ \\
\hline
\end{tabular}




\begin{tabular}{|l|l|l|}
\hline Belgium & Jan 2016 & $\begin{array}{l}\text { Excise tax (€0.068/L) on all non-alcoholic beverages with added sugar or sweeteners } \\
\text { (WCRF, 2017). }\end{array}$ \\
\hline $\begin{array}{l}\text { Berkley, CA } \\
\text { (US) }\end{array}$ & Jan 2015 & $\begin{array}{l}\text { 1-cent per fluid ounce excise tax on the distribution of sugar-sweetened beverages } \\
\text { (containing 2 or more calories per ounce of beverage with added caloric sweetener. Tax } \\
\text { excludes milk products, 100\% juice, diet drinks (City of Berkeley, 2017). }\end{array}$ \\
\hline Chile & Jan 2015 & $\begin{array}{l}\text { Two-tiered ad-valorem tax on sweetened beverages. An existing 13\% tax rate was } \\
\text { increased to 18\% for high-sugar drinks ( }>6.25 \mathrm{~g} \text { of sugar/100ml) and reduced to 10\% for } \\
\text { drinks below the threshold (WCRF, 2017). }\end{array}$ \\
\hline
\end{tabular}

Table 2. Impact of soda taxes on purchases and consumption of beverages

\begin{tabular}{|c|c|c|c|}
\hline Country & Study & Data & Findings \\
\hline $\begin{array}{l}\text { UK (voluntary } \\
\text { levy on sugary } \\
\text { drinks in a } \\
\text { restaurant chain) }\end{array}$ & $\begin{array}{l}\text { (Cornelsen } \\
\text { et al., 2017) }\end{array}$ & $\begin{array}{l}\text { Number of beverages sold } \\
\text { per customer using } \\
\text { electronic point of sale } \\
\text { data records ( } 37 \text { individual } \\
\text { restaurants) }\end{array}$ & $\begin{array}{l}\text { At } 12 \text {-weeks post-levy sales were } 11 \% \text { lower in } \\
\text { comparison to } 12 \text {-weeks pre-levy and at } 6 \text {-months } \\
\text { post-levy, sales were } 9 \% \text { lower. Effects were larger in } \\
\text { restaurants with higher baseline purchases of sugary } \\
\text { drinks. }\end{array}$ \\
\hline \multirow{5}{*}{$\begin{array}{l}\text { Mexico ( } 8 \% \text { tax } \\
\text { on foods high in } \\
\text { sugar, salt and } \\
\text { fat; peso-per- } \\
\text { litre tax on SSB) }\end{array}$} & $\begin{array}{l}\text { (Batis et al., } \\
2016)\end{array}$ & $\begin{array}{l}\text { Urban household ( } \mathrm{n}=6,248) \\
\text { expenditures on taxed } \\
\text { foods, evaluated one year } \\
\text { post-tax }\end{array}$ & $\begin{array}{l}5.1 \% \text { reduction in purchases of taxed foods }(10.2 \% \text { in } \\
\text { low-SES, } 5.8 \% \text { in mid-SES and no change in high-SES } \\
\text { households); no change in purchases of non-taxed } \\
\text { products. }\end{array}$ \\
\hline & $\begin{array}{l}\text { (Colchero } \\
\text { et al., 2016) }\end{array}$ & $\begin{array}{l}\text { Urban household }(n=6,253) \\
\text { expenditures on SSBs one } \\
\text { year post-tax }\end{array}$ & $\begin{array}{l}6.1 \% \text { reduction in sales ( } 9.1 \% \text { among low-SES and } 5.5 \% \\
\text { among mid- and high-SES households). } 4 \% \text { increase in } \\
\text { purchases of non-taxed beverages (mainly water). }\end{array}$ \\
\hline & $\begin{array}{l}\text { (Barrientos- } \\
\text { Gutierrez } \\
\text { et al., 2017) }\end{array}$ & $\begin{array}{l}\text { Estimation of health } \\
\text { impacts using Markov } \\
\text { modelling based on } \\
\text { (Colchero et al. 2016) } \\
\text { estimates of reduction in } \\
\text { beverage purchases } \\
\end{array}$ & $\begin{array}{l}\text { Tax modelled to lead to a } 2.5 \% \text { reduction in obesity } 10 \\
\text { years post implementation; tax estimated to prevent } \\
86-134 \mathrm{~K} \text { cases of diabetes. }\end{array}$ \\
\hline & $\begin{array}{l}\text { (Colchero } \\
\text { et al., } \\
2017 b)\end{array}$ & $\begin{array}{l}\text { Urban household }(n=6,645) \\
\text { expenditures on SSBs two } \\
\text { years post-tax }\end{array}$ & $\begin{array}{l}\text { Average reduction of purchases of taxed products was } \\
6.7 \% \text { in } 2014 \text { and } 9.7 \% \text { in } 2015 \text {. Over the two years, } \\
\text { average increase in purchases of untaxed beverages } \\
\text { by } 2.1 \% \text {. }\end{array}$ \\
\hline & $\begin{array}{l}\text { (Colchero } \\
\text { et al., } \\
\text { 2017a) }\end{array}$ & $\begin{array}{l}\text { National Income and } \\
\text { Expenditure Survey ( } 4 \\
\text { rounds) ( } n=75,954 \\
\text { households) }\end{array}$ & $\begin{array}{l}\text { An average of } 6.3 \% \text { reduction in the observed } \\
\text { purchases of SSBs in } 2014 \text { in comparison to expected } \\
\text { purchases based on trends from 2008-2012. } \\
\text { Reductions were higher among low-income } \\
\text { households, in urban areas and households with } \\
\text { children. A } 16 \% \text { increase in purchases of water } \\
\text { observed among low- and middle income households. }\end{array}$ \\
\hline \multirow[t]{2}{*}{$\begin{array}{l}\text { Berkley (penny- } \\
\text { per-ounce of } \\
\text { SSBs) }\end{array}$} & $\begin{array}{l}\text { (Falbe et } \\
\text { al., 2016) }\end{array}$ & $\begin{array}{l}\text { Pre- }(n=990) \text { and post- } \\
\text { implementation ( } n=1689) \\
\text { survey of self-reported } \\
\text { changes in consumption }\end{array}$ & $\begin{array}{l}21 \% \text { reduction in consumption of taxed beverages; } \\
63 \% \text { increase in consumption of water. }\end{array}$ \\
\hline & $\begin{array}{l}\text { (Silver et } \\
\text { al., 2017) }\end{array}$ & $\begin{array}{l}\text { Electronic point-of-sale } \\
\text { data ( } 15.5 \mathrm{~m} \text { price } \\
\text { observations), telephone } \\
\text { surveys of }(\mathrm{n}=957) \\
\text { consumers }\end{array}$ & $\begin{array}{l}\text { 9.6\% reduction in purchases of taxed beverages, and } \\
\text { increased purchases of non-taxed beverages by } 3.5 \% \\
\text { (water } 15.6 \% \text {, juice } 3.4 \% \text {, milk } 0.6 \% \text { ); no change in self- } \\
\text { reported intake of SSBs but increased intake of } \\
\text { calories from dairy-based drinks. }\end{array}$ \\
\hline
\end{tabular}




\section{References}

AGENCE FRANCE-PRESSE 2016. Portugal to levy sugar tax on soft drinks in 2017. The Guardian, , 15 Oct 2016.

AGENCIA TRIBUTARIA DE CATALUNYA. 2017. IMPOST SOBRE BEGUDES ENSUCRADES ENVASADES (IBEE) [Online].

Available:

http://economia.gencat.cat/web/.content/70 tributs/arxius/2017/FAQS-3.pdf [Accessed 09.08.17.

ALVARADO, M., KOSTOVA, D., SUHRCKE, M., HAMBLETON, I., HASSELL, T., SAMUELS, T. A., ADAMS, J. \& UNWIN, N. 2017. Trends in beverage prices following the introduction of a tax on sugarsweetened beverages in Barbados. Preventive Medicine.

AN, R. \& MAURER, G. 2016. Consumption of sugar-sweetened beverages and discretionary foods among US adults by purchase location. Eur J Clin Nutr, 70, 1396-1400.

ANDREYEVA, T., LONG, M. W. \& BROWNELL, K. D. 2010. The Impact of Food Prices on Consumption: A Systematic Review of Research on the Price Elasticity of Demand for Food. American Journal of Public Health, 100, 216-222.

AUTORIDADE TRIBUTARIA E ADUANEIRA. 2017. CÓDIGO DOS IMPOSTOS ESPECIAIS DE CONSUMO (CIEC). CIEC (Decreto-Lei n.o 73/2010, de 21/06) [Online]. Available: http://www.dgaiec.minfinancas.pt/NR/rdonlyres/314EF2B6-7EFE-4BF5-A8F2-4D8B61082810/0/CIEC.pdf.

BAQUERO, C. S. 2017. Catalonia region introduces 'soda tax' on sugary drinks. El Pais, 02.05.17.

BARRIENTOS-GUTIERREZ, T., ZEPEDA-TELLO, R., RODRIGUES, E. R., COLCHERO-ARAGONÉS, A., ROJASMARTÍNEZ, R., LAZCANO-PONCE, E., HERNÁNDEZ-ÁVILA, M., RIVERA-DOMMARCO, J. \& MEZA, R. 2017. Expected population weight and diabetes impact of the 1-peso-per-litre tax to sugar sweetened beverages in Mexico. PLOS ONE, 12, e0176336.

BATIS, C., RIVERA, J., POPKIN, B. \& SMITH TAILLIE, L. 2016. First-Year Evaluation of Mexico's Tax on Nonessential Energy-Dense Foods: An Observational Study. Plos Medicine, 13, e100205.

BERARDI, N., SEVESTRE, P., TEPAUT, M. \& VIGNERON, A. 2016. The impact of a 'soda tax' on prices: evidence from French micro data. Applied Economics, 48, 3976-94.

BSDA. 2017. Changing Tastes: The UK Soft Drinks Annual Report 2016 [Online]. London: British Soft Drinks Association.

Available:

www.britishsoftdrinks.com/write/mediauploads/.../bsda annual report 2015.pdf [Accessed 10.08.17.

BURKI, T. 2017. Tax on tobacco and sugary drinks in the United Arab Emirates. The Lancet Oncology, 18, e566.

CABRERA ESCOBAR, M. A., VEERMAN, J. L., TOLLMAN, S. M., BERTRAM, M. Y. \& HOFMAN, K. J. 2013. Evidence that a tax on sugar sweetened beverages reduces the obesity rate: a meta-analysis. BMC Public Health, 13, 1072.

CALANTUONI, F. \& ROJAS, C. 2015. THE IMPACT OF SODA SALES TAXES ON CONSUMPTION: EVIDENCE FROM SCANNER DATA. Contemporary Economic Policy, 33, 714-34.

CAWLEY, J. \& FRISVOLD, D. 2017. The Pass-Through of Taxes on Sugar-Sweetened Beverages to Retail Prices: The Case of Berkeley, California. Journal of Policy Analysis and Management, 36, 30326.

CHANTANUSORNSIRI, W. 2017. Six-year plan for sugary drink taxes. Bangkok Post, 24.07.17.

CHEN, X., KAISER, H. M. \& RICKARD, B. J. 2015. The impacts of inclusive and exclusive taxes on healthy eating: An experimental study. Food Policy, 56, 13-24.

CHETTY, R., LOONEY, A. \& KROFT, K. 2009. Salience and Taxation: Theory and Evidence. Am Econ Rev, 99, 1145-77.

CITY OF ALBANY. 2017. Frequently Asked Questions for the Sweetened Beverage Tax of Albany, CA [Online]. Available: http://www.albanyca.org/recreation/faq/-seldept-5 [Accessed 24.07.2017.

CITY OF BERKELEY. 2017. Frequently Asked Questions for the Sweetened Beverage Tax of Berkeley, CA [Online]. Available: http://www.ci.berkeley.ca.us/uploadedFiles/Finance/Level 3 - 
General/Frequently\%20Asked\%20Questions\%20Edited\%20Version\%20111015.2.pdf

[Accessed 08.08.17.

CITY OF BOULDER. 2017. City of Boulder Sugar Sweetened Beverage Product Distribution Tax. Frequently Asked Questions [Online]. Available: https://wwwstatic.bouldercolorado.gov/docs/SSBPDT-FAQ-1-201702231116.pdf [Accessed 24.07.2017.

CITY OF OAKLAND. 2016. Sugar Sweetened Beverage Tax, Frequently Asked Questions [Online]. Available: http://www2.oaklandnet.com/w/OAK063793 [Accessed 09.08.17.

CITY OF PHILADELPHIA. 2017. Philadelphia Beverage Tax [Online]. Available: https://beta.phila.gov/services/payments-assistance-taxes/business-taxes/philadelphiabeverage-tax/ [Accessed 09.08.17.

COlCheRO, A., MOLINA, M. \& GUERRERO-LOPEZ, C. 2017a. After Mexico Implemented a Tax, Purchases of Sugar-Sweetened Beverages Decreased and of Water Increased: Difference by Place of Residence, Household Composition, and Income Level. The Journal of Nutrition, doi: 10.3945/jn.117.251892.

COLCHERO, A., POPKIN, B., RIVERA, J. \& NG, S. 2016. Beverage purchases from stores in Mexico under the excise tax on sugar sweetened beverages: observational study. BMJ, 352:h6704.

COLCHERO, A., RIVERA-DOMMARCO, J., POPKIN, B. \& NG, S. 2017b. In Mexico, Evidence of Sustained Consumer Response Two Years After Implementing A Sugar-Sweetened Beverage Tax. Health Affairs, 36, 564-71.

COLCHERO, A., SALGADO, J., UNAR-MUNGUIA, M., MOLINA, M., NG, S. \& RIVERA-DOMMARCO, J. 2015. Changes in Prices After an Excise Tax to Sweetened Sugar Beverages Was Implemented in Mexico: Evidence from Urban Areas. PLOS ONE, 10, e0144408. doi:10.1371/journal.pone.0144408.

COOK COUNTY GOVERNMENT. 2017. Sweetened Beverage Tax [Online]. Available: https://www.cookcountyil.gov/service/sweetened-beverage-tax [Accessed 09.08.17.

CORNELSEN, L. \& CARREIDO, A. 2015. Health-related taxes on food and beverages. Food Research Collaboration Policy Brief. London.

CORNELSEN, L., GREEN, R., DANGOUR, A. \& SMITH, R. 2014. Why fat taxes won't make us thin. Journal of Public Health, 37, 18-23.

CORNELSEN, L., MYTTON, O., ADAMS, J., GASPARRINI, A., ISKANDER, D., KNAI, C., PETTICREW, M., SCOTT, C., SMITH, R., THOMPSON, C., WHITE, M. \& CUMMINS, S. 2017. Change in nonalcoholic beverage sales following a 10-pence levy on sugar-sweetened beverages within a national chain of restaurants in the UK: interrupted time series analysis of a natural experiment. J Epidemiol Community Health, doi:10.1136/jech-2017-209947.

DANESHKU, S. 2017. Budget 2017: Revenues from UK's incoming sugar tax fall short. Financial Times, 08.03.2017.

DEPARTMENT OF FINANCE. 2016. Sugar-sweetened drinks tax. Public Consultation [Online]. Dublin: Department of Finance, Tax Policy Division. Available: http://www.budget.gov.ie/Budgets/2017/Documents/SugarSweetened Drinks Tax Public Consultation final.pdf [Accessed 08.08.17.

ELLIOTT-GREEN, A., HYSENI, L., LLOYD-WILLIAMS, F., BROMLEY, H. \& CAPEWELL, S. 2016. Sugarsweetened beverages coverage in the British media: an analysis of public health advocacy versus pro-industry messaging. BMJ Open, 6.

ERR. 2017. Finance committee against adopting sweetened beverage tax unchanged [Online]. Available: http://news.err.ee/632560/finance-committee-against-adopting-sweetenedbeverage-tax-unchanged [Accessed 12.10.2017.

EUROMONITOR PASSPORT 2015. Where are our calories coming from? Actions being taken to improve nutrition.

FALBE, J., ROJAS, N., GRUMMON, A. \& MADSEN, K. 2015. Higher Retail Prices of Sugar-Sweetened Beverages 3 Months After Implementation of an Excise Tax in Berkeley, California. Am J Pub Health, 15, 2194-2201. 
FALBE, J., THOMPSON, H., BECKER, C., ROJAS, N., MCCULLOCH, C. \& MADSEN, K. 2016. Impact of the Berkeley Excise Tax on Sugar-Sweetened Beverage Consumption. Am J Pub Health, doi: 10.2105/AJPH.2016.303362.

GALLET, C. A. \& LIST, J. A. 2003. Cigarette demand: a meta-analysis of elasticities. Health Economics, $12,821-835$.

GENERALITAT DE CATALUNYA. 2017. Tax on sugary drinks [Online]. Available: http://web.gencat.cat/en/actualitat/detall/Impost-sobre-begudes-ensucrades [Accessed 09.08.17.

GORYAKIN, Y., MONSIVAIS, P. \& SUHRCKE, M. 2017. Soft drink prices, sales, body mass index and diabetes: Evidence from a panel of low-, middle- and high-income countries. Food Policy, 73, 88-94.

GREEN, R., CORNELSEN, L., DANGOUR, A., TURNER, R., SHANKAR, B., MAZZOCCHI, M. \& SMITH, R. 2013. The effect of rising food prices on food consumption: systematic review with metaregression. BMJ 346: $\mathbf{f 3 7 0 3 .}$

HM TREASURY. 2016a. Consultation outcome Soft Drinks Industry Levy [Online]. Available: https://www.gov.uk/government/consultations/soft-drinks-industry-levy [Accessed 10.08.17.

HM TREASURY. 2016b. Soft Drinks Industry Levy: 12 things you should know [Online]. HM Revenue \& Customs, Department of Health. Available: https://www.gov.uk/government/news/softdrinks-industry-levy-12-things-you-should-know [Accessed 10.08.17.

IARC 2011. Chapter 4. Tax, price and aggregate demand for tobacco products. Effectiveness of tax and price policies for tobacco control. Lyon, France.

JEONG, M., GILMORE, J. S., BLEAKLEY, A. \& JORDAN, A. 2014. Local News Media Framing of Obesity in the Context of a Sugar-Sweetened Beverage Reduction Media Campaign. Journal of Nutrition Education and Behavior, 46, 583-588.

JHA, P. 2009. Avoidable global cancer deaths and total deaths from smoking. Nat Rev Cancer, 9, 65564.

JITPLEECHEEP, P. 2017. Sermsuk seeks to reduce sugar content for new tax. Bangkok Post, 09.10.2017. NATIONAL TREASURY REPUBLIC OF SOUTH AFRICA. 2016. Taxation of Sugar Sweetened Beverages. Policy paper [Online]. Economics Tax Analysis Chief Directorate. Available: http://www.treasury.gov.za/public\%20comments/Sugar\%20sweetened\%20beverages/POLI CY\%2OPAPER\%20AND\%20PROPOSALS\%200N\%20THE\%20TAXATION\%20OF\%20SUGAR\%20S WEETENED\%20BEVERAGES-8\%20JULY\%202016.pdf. [Accessed 09.08.17.

NATIONAL TREASURY REPUBLIC OF SOUTH AFRICA. 2017. Tax on Sugary Beverages [Online]. Available: http://www.treasury.gov.za/public\%20comments/Sugar\%20sweetened\%20beverages/2017 022701\%20-\%20QandA\%20Tax\%20on\%20Sugary\%20Beverages.pd [Accessed 09.08.17.

NIEDERDEPPE, J., GOLLUST, S. E., JARLENSKI, M. P., NATHANSON, A. M. \& BARRY, C. L. 2013. News Coverage of Sugar-Sweetened Beverage Taxes: Pro- and Antitax Arguments in Public Discourse. American Journal of Public Health, 103, e92-e98.

NIXON, L., MEJIA, P., CHEYNE, A. \& DORFMAN, L. 2015. Big Soda's long shadow: news coverage of local proposals to tax sugar-sweetened beverages in Richmond, El Monte and Telluride. Critical Public Health, 25, 333-347.

NORIMINE, H. 2017. City Council Approves Soda Tax Seattle Met, 06.06.17.

OFFICE OF THE CITY CLERK 2017. AN ORDINANCE imposing a tax on engaging in the business of distributing sweetened beverages. In: CITY OF SEATTLE, O. O. T. C. C. (ed.). USA.

OXFORD ECONOMICS. 2016. The Economic Impact of the Soft Drinks Levy [Online]. Available: http://www.britishsoftdrinks.com/write/MediaUploads/Publications/The Economic Impact of the Soft Drinks Levy.pdf [Accessed 10.08.17.

PAARLBERG, R., MOZAFFARIAN, D. \& MICHA, R. 2017. Viewpoint: Can U.S. local soda taxes continue to spread? Food Policy, 71, 1-7. 
PENNEY, T., ADAMS, J., BRIGGS, A., CUMMINS, S., HARRINGTON, R., MONSIVAIS, P., MYTTON, O., RAYNER, M., RUTTER, H., SCARBOROUGH, P., SMITH, R. \& WHITE, M. 2017. Evaluation of the impacts on health of the proposed UK industry levy on sugar sweetened beverages: developing a systems map and data platform, and collection of baseline and early impact data [Online]. Available: https://www.journalslibrary.nihr.ac.uk/programmes/phr/164901/\#/ [Accessed 23.10.17.

RICHARDSON, B. 2016. Sugar Shift: Six Ideas for a Healthier and Fairer Food System. London: Food Research Collaboration.

ROACHE, S. A. \& GOSTIN, L. O. 2017. The Untapped Power of Soda Taxes: Incentivizing Consumers, Generating Revenue, and Altering Corporate Behavior. International Journal of Health Policy and Management, 6, 489-493.

SAVELL, E., GILMORE, A., SIMS, M., MONY, P. \& AL., E. 2015. The environmental profile of a community's health: a cross-sectional study on tobacco marketing in 16 countries. Bulletin of the World Health Organisation, 93.

SILVER, L., NG, S., RYAN-IBARRA, S., SMITH TAILLIE, L., INDUNI, M., MILES , D., POTI, J. \& POPKIN, B. 2017. Changes in prices, sales, consumer spending, and beverage consumption one year after a tax on sugar-sweetened beverages in Berkeley, California, US: A before-and-after study. Plos Medicine, 14, e1002283.

THE PORTUGAL NEWS ONLINE. 2017. Government prepares "smarter" sugar tax revamp [Online]. Available: $\quad$ http://theportugalnews.com/news/government-prepares-smarter-sugar-taxrevamp/42249 [Accessed 09.08.17.

TREASURER\&TAX COLLECTOR. 2017. Sugary Drinks Tax Frequently Asked Questions [Online]. City and County of San Francisco. Available: http://sftreasurer.org/sugary-drinks-tax-frequentlyasked-questions-faq [Accessed 24.07.17.

VEERMAN, J. L. \& THAI, T. 2017. The potential health effects of taxing sugary drinks in Estonia [Online]. Cancer Council NSW. Available: https://www.sm.ee/sites/default/files/contenteditors/Uudised pressiinfo/the potential health effects of taxing sugary drinks in esto nia.pdf [Accessed 03.08.17.

VIEUX, F., MAILLOT, M., CONSTANT, F. \& DREWNOWSKI, A. 2017. Water and beverage consumption patterns among 4 to 13-year-old children in the United Kingdom. BMC Public Health, 17, 479.

WADA, R., HAN, E. \& POWELL, L. M. 2015. Associations between soda prices and intake: Evidence from 24-h dietary recall data. Food Policy, 55, 54-60.

WCRF. 2017. NOURISHING framework - Use economic tools to address food affordability and purchase and incentives - Health-related food taxes [Online]. Available: http://www.wcrf.org/int/policy/nourishing-framework.

WHO. 2017. Parliament in Estonia approves legislation taxing soft drinks [Online]. Available: http://www.euro.who.int/en/countries/estonia/news/news/2017/06/parliament-in-estoniaapproves-legislation-taxing-soft-drinks [Accessed 03.08.17.

ZHENG, Y., EW, M. \& KAISER, H. M. 2013. Taxing Food and Beverages: Theory, Evidence, and Policy. American Journal of Agricultural Economics, 95, 705-23. 